\title{
At-Taqaddum
}

Vol. 11 No. 2 (2019) pp 142-167

DOI: http://dx.doi.org/10.21580/at.v1li2.4445

\section{IMPLEMENTASI ZAKAT PENGHASILAN SEBAGAI PENGURANG PENGHASILAN KENA \\ PAJAK PERORANGAN \\ (Studi Kasus Muzaki di BAZNAS Kabupaten Semarang)}

Sofia Fuadah, Arif Afendi

Fakultas Ekonomi dan Bisnis Islam UIN Walisongo

Email : Sofia_fuadah@yahoo.co.id, arifafendi@walisongo.ac.id

\begin{abstract}
Tax is a obligatory payment to the country by a person or company and one of the bighest source of income for a country. Amid the increasing role of taxes in this country revenue, raising awareness of Muslims on the role of zakat. This requires the proper management of Zakat and Tax. The government strives to minimize the double obligation by making regulations that can be a solution, namely Law Number 36 of 2008 concerning Income Tax and Law No. 23 of 2011 concerning Management of Zakat.The purpose of this study was to find out the Implementation of Income Zakat as a Deduction of Personal Taxable Income on muzaki in BAZNAS Semarang Regency and the Impact of Implementation of Income Zakat as a Deduction of Taxable Income for State Revenues and Community Welfare. The method used in this study is a field research method conducted with a qualitative approach. The technique of collecting data is done by observation, interviews, and documentation. The descriptive analytical analysis is used as the method. The results showed that muraki in $B A Z N A S$ Semarang District had implemented the policy even though it was still in a relatively low percentage, this was due to a lack of socialization from BAZNAS and KPP Pratama and a lack of community trust towards zakat management institutions. The policy has an impact on increasing the amount of zakat even though state revenues are reduced. The amount of zakat paid by muzaki can be used to assist the Government in alleviating poverty, because besides being distributed to 8 ashnaf, the funds can be used for empowerment programs that include Semarang Care, Semarang Healthy, Semarang Clever and Semarang Prosper.
\end{abstract}

Keywords: Zakat, Tax, Income 


\begin{abstract}
Abstrak
Pajak adalah kontribusi wajib kepada negara oleh pribadi atau badan yang bersifat memaksa dan merupakan sumber penerimaan tertinggi bagi suatu negara. Ditengah menguatnya peranan pajak dalam penerimaan negara ini, secara bersamaan muncul kesadaran umat Islam akan peranan zakat. Dengan adanya hal ini menuntut pengelolaan yang tepat antara Zakat dan Pajak. Pemerintah berupaya untuk meminimalkan kewajiban ganda tersebut dengan membuat peraturan yang dapat menjadi solusi yaitu Undang-Undang Nomor 36 Tahun 2008 Tentang Pajak Penghasilan dan Undang-Undang No. 23 Tahun 2011 tentang Pengelolaan Zakat.

Tujuan penelitian ini adalah untuk mengetahui Implementasi dari Zakat Penghasilan sebagai Pengurang Penghasilan Kena Pajak Orang Pribadi pada Muzaki di BAZNAS Kabupaten Semarang dan Dampak Implementasi Zakat Penghasilan sebagai Pengurang Penghasilan Kena Pajak Bagi Penerimaan Negara dan Kesejahteraan Masyarakat. Metode yang digunakan dalam penelitian ini adalah metode penelitian lapangan yang dilakukan dengan pendekatan kualitatif. Teknik pengumpulan data dilakukan dengan observasi, wawancara, dan dokumentasi. Metode analisis yang digunakan adalah metode analisis deskriptif-analitis.

Hasil penelitian menunjukkan bahwa Muzaki di BAZNAS Kabupaten Semarang sudah menerapkan kebijakan tersebut meskipun masih dalam prosentase yang relatif rendah hal ini terjadi karena kurangnya sosialisasi dari pihak BAZNAS dan KPP Pratama dan kurangnya rasa percaya masyarakat terhadap lembaga pengelola zakat. Kebijakan tersebut berdampak pada meningkatnya jumlah zakat meskipun penerimaan negara berkurang. Jumlah zakat yang dibayarkan muzaki dapat digunakan untuk membantu Pemerintah dalam mengentaskan kemiskinan, karena selain disalurkan kepada 8 ashnaf, dana tersebut dapat digunakan untuk program pemberdayaan yang meliputi Semarang Peduli, Semarang Sehat, Semarang Cerdas dan Semarang Makmur.
\end{abstract}

Kata Kunci: Zakat, Pajak, Penghasilan 


\section{At-Taqaddum}

Vol. 11 No. 2 (2019) pp 142-167

DOI: http://dx.doi.org/10.21580/at.v11i2.4445

\section{Pendahuluan}

Menurut Undang-undang Nomor 28 Tahun 2007 tentang perpajakan, Pajak merupakan "kontribusi wajib kepada negara yang terutang oleh pribadi atau badan yang bersifat memaksa berdasarkan undang - undang dengan tidak mendapatkan imbalan secara langsung dan digunakan untuk keperluan negara bagi sebesar-besarnya kemakmuran rakyat". ${ }^{1}$ Adapun ciri-ciri tentang pajak diantaranya adalah iuran atau kontribusi wajib rakyat kepada negara, dipungut oleh Pemerintah berdasarkan undang-undang sehingga bersifat memaksa, tanpa jasa timbal balik atau kontra-prestasi secara langsung yang dapat ditunjuk, digunakan untuk membiayai pengeluaran umum sehubungan dengan penyelenggaraan pemerintahan, secara khusus, undang-undang menambahkan bahwa penggunaan iuran pajak adalah untuk sebesarbesarnya kemakmuran rakyat (pemerataan kesejateraan). ${ }^{2}$

Di Indonesia, dominasi pajak sebagai pos penerimaan dalam negeri telah terlihat sejak awal berdirinya negara ini. Berdasarkan pada data APBN dari tahun ketahun yang secara rutin dipublikasikan oleh Departemen Keuangan, diperoleh informasi bahwa penerimaan dari sektor perpajakan telah memberikan sokongan yang cukup signifikan, yaitu diatas $50 \%$ dari total penerimaan negara. Setiap tahunnya kontribusi pajak mengalami kenaikan, pada tahun 2008 sebesar 70,3\%, tahun 2009 sebesar 72,5\%, tahun 2010 sebesar 80\% dan sampai tahun 2017 naik sebesar $83 \%$. Dari data tersebut cukup jelas bahwa kontribusi pajak mengalami peningkatan yang cukup signifikan terhadap penerimaan negara.

Salah satu pajak yang dipungut oleh pemerintah adalah pajak atas penghasilan yang mana diatur dalam Undang-Undang Nomor 36 Tahun 2008 Pasal 4 ayat (1) penghasilan didefinisikan sebagai setiap tambahan kemampuan ekonomis yang diterima atau diperoleh oleh wajib pajak, baik

${ }^{1}$ Undang - Undang Nomor 28 Tahun 2007 Pasal 1 ayat (1) Tentang Ketentuan Umum dan Tata Cara Perpajakan.

${ }^{2}$ Herry Purwanto, Dasar - dasar Perpajakan \& Akuntansi Pajak, Jakarta: Erlangga, 2010, h. 7 . 
yang berasal dari Indonesia maupun dari luar Indonesia, yang dapat dipakai untuk menambah kekayaan wajib pajak yang bersangkutan, dengan nama dan dalam bentuk apapun. ${ }^{3}$ Dengan adanya peraturan tersebut negara menuntut setiap warganya untuk menyerahkan sebagian kekayaan untuk negara yang akan digunakan untuk biaya pembangunan dan pemeliharaan negara.

Sumber pajak di Indonesia sebagian besar berada ditangan penduduk muslim. Sebagaimana telah diketahui, penduduk muslim di Indonesia berjumlah $87,2 \%$ dari total seluruh penduduk yang ada atau sekitar 207.176.162 jiwa. $^{4}$ Berdasarkan data dari Kementerian Keuangan Republik Indonesia potensi pajak di Indonesia mencapai Rp 1.427,7 T pada tahun $2017^{5}$ akan tetapi jumlah tersebut berbanding terbalik dengan pemasukan yang ada yaitu sebesar Rp 1.283,6 T. ${ }^{6}$ Ditengah menguatnya peranan pajak dalam penerimaan negara ini, secara bersamaan muncul kesadaran umat Islam akan peranan zakat, dan ini yang menjadi masalah dimasyarakat dan menyebabkan banyak dari mereka yang kurang patuh dan taat dalam membayar pajak maupun zakat. ${ }^{7}$

Zakat merupakan pilar agama karena ia bagian dari rukun Islam yang lima. Zakat secara etimologi didefinikan sebagai sejumlah harta tertentu yang telah mencapai syarat tertentu yang diwajibkan Allah untuk dikeluarkan dan diberikan kepada orang-orang yang berhak menerimanya. ${ }^{8}$

Dalam Al-Qur'an dijelaskan 7 jenis harta benda yang wajib dizakatkan; yakni emas, perak, hasil tanam - tanaman dan buah - buahan, barang dagangan, tambang dan barang temuan. Akan tetapi ada beberapa

\footnotetext{
${ }^{3}$ Undang - Undang Nomor 36 Pasal 4 ayat (1) Tahun 2008 Tentang Pajak Penghasilan.

${ }^{4}$ Badan Pusat Statistik, Population Census 2010.

${ }^{5}$ www.kemenkeu.go.id/apbn2018 diakses januari 2019.

${ }^{6}$ www.online-pajak.com diakses januari 2019.

${ }^{7}$ Sri Andriani, Zakat Sebagai Pengurang Pajak Penghasilan Pada Badan Amil Zakat, JRAK Vol. 4 No. 1, Februari 2013, h. 15.

${ }^{8}$ Saifudin Zuhri, Zakat di Era Reformasi (Tata kelola Baru) Undang - Undang Pengelolaan Zakat No. 23 Tahun 2011, Semarang: Fakultas Tarbiyah IAIN Walisongo Semarang, 2012, h. 1.
} 


\section{At-Taqaddum}

Vol. 11 No. 2 (2019) pp 142-167

DOI: http://dx.doi.org/10.21580/at.v1li2.4445

harta-harta penghasilan lainnya jika dilihat dari rentan waktu dan ukuran nisabnya sudah layak untuk dizakatkan seperti profesi dokter, pengacara, pegawai negeri dan sebagainya. Dengan alokasi zakat yang hanya diperuntukan bagi 8 golongan (ashnaf) saja, yaitu: orang-orang fakir (fuqara'), miskin (masakin), amil zakat ('amilin 'alayha), mualaf (mu'allaf qulububum), budak (riqab), orang-orang yang berhutang (gharimin), pejuang di jalan Allah (fii sabilillab), dan musafir (ibn sabil). Di dalam Al-Qur'an Allah SWT telah menjelaskan secara jelas berbagai ayat zakat. Jadi dapat disimpulkan bahwa zakat merupakan rukun Islam terpenting setelah sholat. Pelaksanaan zakat melambangkan hubungan dengan Allah S.W.T dan sesama manusia. Ayat Al-Qur'an yang menjelaskan tentang zakat diantaranya adalah QS Al-Baqoroh; 267 yang berbunyi:

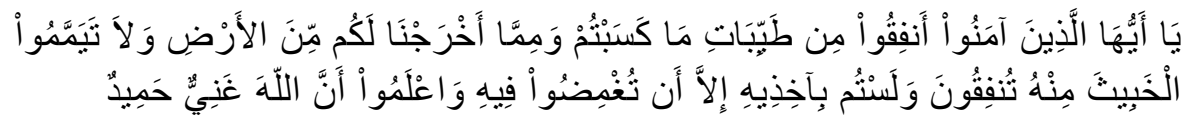

Artinya :'Hai orang-orang yang beriman, nafkahkanlah (di jalan allah) sebagian dari hasil usahamu yang baik-baik dan sebagian dari apa yang Kami keluarkan dari bumi untuk kamu. Dan janganlah kamu memilih yang buruk-buruk lalu kamu menafkahkan daripadanya, padahal kamu sendiri tidak mau mengambilnya melainkan dengan memincingkan mata terhadapnya. Dan ketahuilah, bahwa Allah Maha Kaya lagi Maha Terpuji" (Al-Baqoroh;267). ${ }^{9}$

Di Indonesia, seorang muzaki (wajib zakat) juga wajib pajak ketika memenuhi ketentuan kewajiban pajak yang telah ditentukan pemerintah. Dengan adanya hal ini menuntut pengelolaan yang tepat antara zakat dan pajak. Undang - Undang Nomor 23 Tahun 2011 Pasal 22 menyebutkan "zakat yang dibayarkan oleh muzaki kepada BAZNAZ atau LAZ dikurangkan dari penghasilan kena pajak". ${ }^{10}$ Dalam Pasal 4 ayat (1) menyatakan bahwa zakat meliputi zakat mal dan zakat fitrah. ${ }^{11}$ Dilihat dari

\footnotetext{
${ }^{9}$ Kementerian Agama RI, Ummul Mukminin Al-Qur'an dan Terjemahan untuk Wanita, Jakarta: wali oasis terrace recident, 2016, h. 4

${ }^{10}$ Undang - Undang Nomor 23 Tahun 2011 Pasal 22 Tentang Pengelolaan Zakat.

${ }^{11}$ Undang - Undang Nomor 23 Tahun 2011 Pasal 4 ayat 1 Tentang Pengelolaan Zakat.
} 
kedua jenis zakat dalam Undang-Undang tersebut yang dapat menjadi pengurang penghasilan kena pajak pada pajak penghasilan adalah zakat mal yang diserahkan kepada BAZ atau LAZ.

Dengan adanya fakta mengenai subjek pajak terbesar adalah kaum muslimin yang jumlahnya $87,2 \%$ dari total penduduk Indonesia, pemerintah berupaya untuk meminimalkan kewajiban ganda tersebut. Upaya untuk mengatasinya dilakukan titik temu antara pajak dan zakat sehingga kedua kewajiban tersebut dapat dilaksanakan oleh umat Islam. Pemerintah membuat peraturan yang dapat menjadi solusi yaitu UndangUndang Nomor 36 Tahun 2008 tentang Pajak Penghasilan dan UndangUndang Nomor 23 Tahun 2011 tentang Pengelolaan Zakat. Di dalam Undang-Undang Nomor 36 Tahun 2008 ini, zakat atas penghasilan yang telah dibayarkan oleh wajib pajak beragama Islam kepada badan atau lembaga yang disahkan oleh pemerintah, dapat dikurangkan dari penghasilan bruto Wajib Pajak. ${ }^{12}$ Dengan adanya peraturan ini diharapakan kesejahteraan yang merata dan meningkat untuk semua penduduk masyarakat Indonesia, baik sebagai wajib pajak, muzaki dan Mustahik. ${ }^{13}$

BAZNAS adalah lembaga non struktural yang bersifat mandiri dan bertanggungjawab kepada Presiden melalui Menteri. Di Kabupaten Semarang terdapat badan pengelola zakat yang dikenal dengan nama BAZNAS Kabupaten Semarang. Fungsi dari BAZNAS Kabupaten Semarang yaitu sebagai perencanaan, pelaksanaan, pengendalian pengumpulan, pendistribusian dan pendayagunaan zakat serta pelaporan dan pertanggungjawaban pelaksanaan pengelolaan zakat, infak dan shodaqoh. Badan tersebut dibentuk sesuai dengan SK No. D. J 11/568 tahun 2014 tanggal 05 Juni 2014, yang sebelumnya bernama YAZIS (1988) kemudian berubah menjadi BAZIS (2008).

Sebagai lembaga yang melakukan pengelolaan zakat secara nasional, tujuan utama dari BAZNAS adalah menjadi pengelola zakat

12 Undang - Undang Nomor 36 Tahun 2008 Tentang Pajak Penghasilan. 


\section{At-Taqaddum}

Vol. 11 No. 2 (2019) pp 142-167

DOI: http://dx.doi.org/10.21580/at.v1li2.4445

terbaik dan terpercaya di dunia. Visi tersebut juga menjadi acuan utama bagi BAZNAS Kabupaten Semarang untuk mengoptimalkan potensi zakat karena masih terjadi kesenjangan antara jumlah penduduk dengan jumlah muzaki di BAZNAS Kabupaten Semarang. Seperti yang telah diketahui jumlah penduduk muslim di Kabupaten Semarang sebanyak 1.568.940 jiwa yang tersebar di 19 Kecamatan dan 149 Desa. Dari data tersebut, diketahui hanya 3.140 orang saja yang menjadi muzaki di BAZNAS Kabupaten Semarang dan 1.143 orang yang membayarkan zakat profesinya yang terdiri dari Pegawai PNS SKPD Kabupaten Semarang, Instansi Vertikal, BUMN dan BUMD dan Wiraswasta serta perorangan. ${ }^{14}$

Berdasarkan hal tersebut penyusun tertarik untuk mengetahui dan meneliti tentang bagaimana implementasi zakat sebagai pengurang pajak di BAZNAS Kabupaten Semarang serta dampak dari kebijakan tersebut terhadap penerimaan negara dan kesejahteraan masyarakat, oleh karena itu penyusun melakukan penelitian dengan sampel para muzaki yang ada di lembaga tersebut.

Dalam penelitian terdahulu yang meneliti zakat penghasilan sebagai pengurang penghasilan kena pajak menunjukan hasil yang beragam. Diantaranya penelitian yang dilakukan oleh Mawarni (2016) $)^{15}$ dimana penelitian ini bertujuan untuk mengetahui bagaimana penerapan UU No. 23 pasal 22 tahun 2011 tentang zakat sebagai pengurang penghasilan kena pajak pada muzaki di Dompet Dhuafa Yogyakarta. Dapat disimpulkan bahwa lembaga tersebut masih bersifat pasif dalam menerapkan peraturan yang ada, serta belum optimalnya sosialisasi kepada muzakinya karena lembaga tersebut lebih mengutamakan lingkup kesadaran berzakat muzakinya. Selain itu karena faktor kebiasaan membayar zakat dan pajak secara terpisah.

\footnotetext{
${ }^{14}$ Dokumen BAZNAS Kabupaten Semarang.

15 Intan Oktavia Angga Mawarni, Zakat Sebagai Pengurang Penghasilan Kena Pajak Studi Penerapan Atas Pasal 22 dan 23 Tentang Zakat Sebagai Pengurang Pajak UU No. 23 Tahun 2011 Di Dompet Dhuafa Yogyakarta, Yogyakarta: UIN Sunan Kalijaga, 2016.
} 
Menurut Fathya $(2014)^{16}$ dalam penelitiannya yang bertujuan untuk menganalisis efektivitas perlakuan zakat sebagai pengurang penghasilan pada BAZ Provinsi Jawa Timur, dimana penelitian ini menunjukkan bahwa zakat sebagai pengurang penghasilan kena pajak memiliki pengaruh yang sangat besar terhadap pengurangan penerimaan pajak. untuk itu pelaksanaan Undang-Undang zakat dan pajak harus lebih ditingkatkan lagi pelaksanaanya.

Menurut Mariah (2011) ${ }^{17}$ yang menyimpulkan bahwa dengan adanya Undang-Undang No. 17 tahun 2000 zakat dapat menjadi pengurang penghasilan kena pajak sehingga dapat mengurangi beban ganda kewajibanyang harus dibayarkan oleh kaum muslim, akan tetapi hasilnya belum maksimal dikarenkan beberapa kelemahan antara lain dari segi sosialisasi yang kurang yang mengakibatkan banyaknya masyarakat yang belum mengetahui adanya undang - undang tersebut khususnya untuk daerah bekasi. Selain itu dalam penelitian ini juga dijelaskan perhitungan dari zakat sebagi pengurang penghasilan kena pajak adalah penghasilan bruto dikurangi $2,5 \%$ hasil neto dari pengurangan zakat dibayarkan pajak dengan membawa bukti setoran zakat kepada kantor pajak.

Berdasarkan hasil dari beberapa penelitian sebelumnya yang masih beragam serta pentingnya pemahaman mengenai kebijakan zakat penghasilan sebagai pengurang penghasilan kena pajak, maka mendorong peneliti untuk melakukan penelitian lebih lanjut mengenai tema tersebut. Adapun yang menjadi tujuan dari penelitian ini adalah untuk mengetahui Implementasi Zakat Penghasilan sebagai Pengurang Penghasilan Kena Pajak Orang Pribadi pada muzaki di BAZNAS Kabupaten Semarang serta ingin mengetahui dampak dari Implementasi kebijakan Zakat Penghasilan sebagai Pengurang Penghasilan Kena Pajak Orang Pribadi bagi Penerimaan Negara dan Kesejahteraan Masyarakat.

${ }^{16}$ Fitha Fathya, Perlakuan Zakat Sebagai Pengurang Pajak Penghasilan Pada Badan Amil Zakat (BAZ) Provinsi Jawa Timur, Malang: UIN Maulana Malik Ibrahim, 2014.

${ }_{17}$ Mariah, Zakat Sebagai Pengurang Penghasilan Kena Pajak. Studi Kasus Terhadap Pelaksanaan Undang - Undang Zakat di Kabupaten Bekasi, Jakarta: UIN Syarif Hidayatulloh, 2011. 


\section{At-Taqaddum}

Vol. 11 No. 2 (2019) pp 142-167

DOI: http://dx.doi.org/10.21580/at.v1li2.4445

\section{Landasan Teori}

\section{Zakat}

Secara etimologi (asal kata) zakat dari kata zaka yang berarti berkah, tumbuh, bersih, suci, subur dan baik. ${ }^{18}$ Dipahami demikian sebab zakat merupakan upaya mensucikan diri dari kotoran kikir dan dosa. Menyuburkan pahala melalui pengeluaran sedikit dari nilai harta pribadi untuk kaum yang memerlukan. ${ }^{19}$

Secara harfiah zakat berarti berkah, suci baik dan meningkat. Zakat juga berarti pembersihan diri yang didapatkan setelah pelaksanaan kewajiban membayar zakat. Oleh karena itu, harta benda yang dikeluarkan untuk zakat akan membantu mensucikan jiwa manusia dari sifat mementingkan diri sendiri, kikir dan cinta harta. ${ }^{20}$

Menurut Yusuf al- Qardhawi, zakat adalah sejumlah harta tertentu yang diwajibkan oleh Allah diserahkan kepada orang-orang yang berhak. Sedang menurut Abdurrahman al-Jaziri mendefinikan bahwa zakat adalah penyerahan pemilikan tertentu kepada orang yang berhak menerimanya dengan syarat-syarat tertentu pula. ${ }^{21}$

Hukum zakat itu wajib mutlak dan tidak boleh atau sengaja ditunda waktu pengeluarannya apabila telah mencukupi persyaratan yang berhubungan dengan kewajiban tersebut karena akan mendapatkan siksan akhirat dan dunia. Dasar nash dari zakat diantaranya adalah:

Zakat dibedakan dalam dua kelompok besar, yaitu:

a. Zakat nafs (jiwa) atau zakat fitrah

\footnotetext{
${ }^{18}$ Wahbah az-Zuhaili, Fiqih Zakat Dalam Dunia Modern, Surabaya: Bintang, 2001, h. 01. ${ }^{19}$ Amiruddin Inoed (ed), Anatomi Fiqih Zakat Potret \& Pemahaman Badan Amil Zakat Sumatera Selatan, Yogyakarta: Pustaka Pelajar,2005, h. 8.

${ }^{20}$ Afendi, A. (2018). Pengaruh Variabel Makroekonomi Terhadap Jumlah Penerimaan Zakat di Badan Amil Zakat Nasional (Baznas) Pusat Tahun 2012 - 2016. Muqtasid: Jurnal Ekonomi Dan Perbankan Syariah, 9(1), 54. https://doi.org/10.18326/muqtasid.v9i1.54-69

${ }^{21}$ Abdurrahman al - Jaziri, al-Figh 'ala al-madzabib al-Arba'ah, Cairo: Mathaba'ah alIstiqamah, cet-3, jilid IV, h. 95.
} 
Zakat firtah merupakan zakat jiwa yaitu kewajiban berzakat bagi setiap individu baik untuk orang yang sudah dewasa maupun belum dewasa, dan dibarengi dengan ibadah puasa (shaumm). Zakat firtah wajib dikeluarkan sebelum sholat idhul fitri. Namun, ada pula yang mebolehkan mengeluarkan mulai pertengahan bulan puasa. Di Indonesia, zakat fitrah diukur dengan timbangan beras sebanyak $2,5 \mathrm{~kg}$.

b. Zakat maal (harta/ kekayaan)

Zakat yang dikeluarkan untuk menyucikan harta, apabila harta itu telah memenuhi syarat-syarat wajib zakat. Yusuf Qardhawi menjelaskan dalam bukunya "Hukum Zakat" mengenai kekayaan yang wajib dizakati, yaitu:

1) Zakat emas dan perak

2) Zakat binatang ternak

3) Zakat dagang

4) Zakat pertanian (tanaman dan buah - buahan)

5) Madu dan produksi hewan

6) Barang tambang dari hasil laut

7) Investasi pabrik, gedung

8) Zakat pendapatan usaha (profesi) (Afendi, 2018) ${ }^{22}$

\section{Pajak}

Pajak menurut Undang-Undang Nomor 28 Tahun 2007 Pasal 1 angka 1 adalah kontribusi wajib kepada negara yang terutang oleh orang pribadi atau badan yang bersifat memaksa berdasarkan undang - undang, dengan tidak mendapatkan imbalan secara langsung dan digunakan untuk keperluan negara bagi sebesar-besarnya kemakmuran rakyat. ${ }^{23}$

Sedangkan menurut P.J.A Adriani, Pajak merupakan iuran kepada negara (yang dapat dipaksankan) yang terhutang menurut peraturan

\footnotetext{
22 Afendi, A. (2018). Pengaruh Variabel Makroekonomi Terhadap Jumlah Penerimaan Zakat di Badan Amil Zakat Nasional (Baznas) Pusat Tahun 2012 - 2016. Muqtasid: Jurnal Ekonomi Dan Perbankan Syariah, 9(1), 54. https://doi.org/10.18326/muqtasid.v9i1.54-69

${ }^{23}$ Herry Purwanto, Dasar - Dasar Perpajakan \& Akuntansi Pajak, Jakarta: Erlangga, 2010
} 


\section{At-Taqaddum}

Vol. 11 No. 2 (2019) pp 142-167

DOI: http://dx.doi.org/10.21580/at.v11i2.4445

perundang-undangan tanpa mendapatkan prestasi kembali yang langsung dapat ditunjuk yang digunakan untuk membiayai pengeluaran umum sehubungan dengan tugas negara untuk menyelenggarakan pemerintahan. ${ }^{24}$

Tabel 1. Besarnya Tarif Pajak Penghasilan untuk Wajib Pajak Orang Pribadi dalam negeri

\begin{tabular}{|l|l|}
\hline Lapisan Penghasilan Kena Pajak & Tarif Pajak \\
\hline Sampai dengan Rp 50.000.000 & $5 \%$ \\
\hline Diatas Rp 50.000.000 - Rp 250.000.000 & $15 \%$ \\
\hline Diatas Rp 250.000.000 - Rp 500.000.000 & $25 \%$ \\
\hline Diatas Rp 500.000.000 & $30 \%$ \\
\hline
\end{tabular}

\section{Mekanisme Penerapan Zakat sebagai Pengurang Penghasilan Kena Pajak Orang Pribadi}

Syarat formal agar zakat dapat sebagai pengurang penghasilan kena pajak pada pajak penghasilan adalah: ${ }^{25}$

1. Penghasilan atau harta yang dibayarkan zakatnya merupakan objek pajak, sebagaimana definisi objek pajak pada pasal 4 ayat (1) UndangUndang Nomor 36 Tahun 2008 tentang pajak penghasilan. ${ }^{26}$

2. Harta atau penghasilan tersebut dimiliki dan dibayarkan oleh pemeluk agama Islam, diatur dalam beberapa peraturan antara lain berdasarkan Peraturan Pemerintah Nomor 60 Tahun 2010 pasal 1 ayat (1) huruf a tentang zakat atau sumbangan keagamaan yang bersifat wajib yang dapat dikurangkan dari penghasilan bruto. Selanjutnya berdasarkan Peraturan Menteri Nomor 254/PMK.03/2010 Pasal 1 ayat (1) huruf a dan berdasarkan

\footnotetext{
${ }^{24}$ Apriliana, Analisis Komparatif Antara Perlakuan Zakat Sebagai Pengurang Penghasilan Kena Pajak Dengan Perlakuan Zakat Sebagai Pengurang Langsung Pajak. Pnghasilan, Skripsi, Jakarta: UIN Syarif Hidayatullah, 2010, h. 31.

${ }^{25}$ Selfiana Ferida Lubis, Analisis Yuridis Terhadap Pembayaran Zakat Dalam Pengadaan Pajak Penghasilan, Jurnal, Medan: Universitas Sumatera Utara, 2014.

${ }^{26}$ Undang - Undang Nomor 36 Tahun 2008 Tentang Pajak Penghasilan
} 
Peraturan Direktur Jenderal Pajak Nomor PER -6/PJ/2011 pasal 1 huruf a. ${ }^{27}$

3. Dibayarkan kepada Amil Zakat yang disahkan sesuai dengan undangundang tentang pengelolaan zakat. yang diatur dalam beberapa peraturan antara lain: Berdasarkan Undang-Undang Nomor 36 Tahun 2008 pasal 9 ayat (1) huruf g, Peraturan Pemerintah Nomor 18 Tahun 2009 pasal 2, Peraturan Jenderal Pajak Nomor PER 33/PJ/2011 pasal 1. Mengenai badan amil zakat dan lembaga yang dibentuk Pemerintah diatur pada Peraturan Direktur Jenderal Pajak Nomor PER -15/PJ/2012 yang diganti menjadi PER -11/PJ/2017 tentang Badan/Lembaga yang dibentuk atau disahkan oleh Pemerintah yang ditetapkan sebagai penerima zakat atau sumbangan keagamaan yang sifatnya wajib yang dapat dikurangkan dari penghasilan bruto. ${ }^{28}$

4. Harta atau penghasilan yang merupakan objek pajak tersebut tidak dikenai pajak yang bersifat final.

5. Besarnya presentase yang boleh dikreditkan adalah sebesar kadar zakat yang berlaku dalam peraturan agama Islam yaitu berdasarkan Fatwa Majelis Ulama Indonesia Nomor 3 Tahun 2003 yang mengatur tentang zakat penghasilan menyebutkan kadar zakat penghasilan adalah 2,5\% juga berdasarkan Keputusan Direktur Jenderal Pajak Nomor -163/PJ/2003 pasal 1 ayat (3) yang menyebutkan besarnya zakat yang dapat dikurangkan dari penghasilan kena pajak adalah 2,5\% dari jumlah penghasilan. ${ }^{29}$

6. Harus ada bukti dari Amil zakat. Setiap wajib pajak (WP) sekaligus muzaki yang membayarkan zakatnya melalui BAZNAS akan

\footnotetext{
${ }^{27}$ Peraturan Direktur Jenderal Pajak Nomor PER -6/PJ/2011 Pasal 1 huruf a tentang Pelaksanaan Pembayaran dan Pembuatan Bukti Pembayaran atas Zakat atau Sumbangan Keagamaan yang sifatnya wajib yang dapat dikurangkan dari penghasilan bruto ${ }^{28}$ Peraturan Direktur Jenderal Pajak Nomor PER - 11/PJ/2017 tentang badan/lembaga yang dibentuk atau disahkan oleh Pemerintah yan ditetapkan sebagai penerima zakat atau sumbagan keagamaan yang sifatnya wajib yang dapat dikurangkan dari penghasilan bruto.

${ }^{29}$ Keputusan Direktur Jenderal Pajak Nomor KEP -163/PJ/2003 tentang perlakuan zakat atas penghasilan dalam perhitungan penghasilan kena pajak pajak penghasilan.
} 


\section{At-Taqaddum}

Vol. 11 No. 2 (2019) pp 142-167

DOI: http://dx.doi.org/10.21580/at.v1li2.4445

mendapat Nomor Pokok Wajib Zakat (NPWZ). Dengan melakukan pembayaran zakat, maka Badan Amil Zakat akan memberikan bukti setor zakat (BSZ) kepada wajib zakat sesuai dengan jumlah zakat yang dibayarkan kepada BAZNAS. Bukti Setoran Zakat (BSZ) merupakan salah satu syarat yang harus ada ketika wajib zakat akan melakukan pembayaran pajak agar mendapat pengurangan pembayaran pajak penghasilan. Hal ini didukung dengan adanya Peraturan Menteri Keuangan Nomor 254/PMK.03/2010 menyebutkan "zakat atau sumbangan keagamaan sebagaimana dimaksud dalam pasal 1 ayat (1) yang dikurangkan dari penghasilan bruto oleh pemberi zakat atau sumbangan keagamaan harus didukung bukti-bukti yang sah. ${ }^{30}$

Bukti Setor Zakat (BSZ) tersebut dapat dijadikan bukti yang sah yang dapat dilampirkan pada SPT (surat Pemberitahuan) Tahunan Pajak Penghasilan sebagai pengurang Penghasilan Kena Pajak pada pajak penghasilan harus memenuhi syarat yang terdapat dalam Peraturan Direktur Jenderal Pajak Nomor PER -6/PJ/2011 pasal 2 sebagai berikut: ${ }^{31}$

a. Wajib pajak yang melakukan pengurangan zakat atau sumbangan keagamaan yang sifatnya wajib sebagaimana dimaksud dalam pasal 1, wajib melampirkan foto kopi bukti pembayaran pada surat pemberitahuan (SPT) Tahunan Pajak Penghasilan Tahun Pajak dilakukan pengurangan zakat atau sumbangan keagamaan yang sifatnya wajib.

b. Bukti pembayaran sebagaimana dimaksud pada ayat (1):

1) Dapat berupa bukti pembayaran secara langsung atau melalui transfer rekening bank, atau pembayaran melalui Anjungan Tunai Mandiri (ATM) dan

\footnotetext{
${ }^{30}$ Peraturan Menteri Keuangan Nomor 254/PMK.03/2010 tentang tata cara pembebanan zakat atau sumbangan keagamaan yang sifatnya wajib yang dapat dikurangkan dari penghasilan bruto.

31 Peraturan Direktur Jenderal Pajak Nomor PER -6/PJ/2011 tentang pelaksanaan pembayaran dan pembuatan bukti pembayaran atas zakat atau sumbangan keagamaan yang sifatnya wajib yang dapat dikurangkan dari penghasilan bruto.
} 
2) Paling sedikit memuat:

a. Nama lengkap Wajib Pajak dan Nomor Pokok Wajib Pajak (NPWP)

b. Jumlah pembayaran

c. Tanggal Pembayaran

d. Nama badan amil zakat, lembaga amil zakat atau lembag keagamaan yang dibentuk atau disahkan oleh Pemerintah

e. Tanda tangan petugas badan amil zakat, lembaga amil zakat atau lembag keagamaan yang dibentuk atau disahkan oleh Pemerintah, dibukti pembayaran apabila pembayaran secara langsung atau

f. Validasi petugas bank pada bukti pembayaran melalui transfer rekening bank.

\section{Metodologi Penelitian}

Penelitian ini termasuk dalam jenis penelitian kualitatif. Penelitian ini disebut juga penelitian lapangan (field research), yaitu penyusun melakukan penelitian dengan cara terjun langsung ke lokasi penelitian untuk memperoleh data dan informasi yang diperlukan bagi penyusun, yakni muzaki di BAZNAS Kabupaten Semarang yang berkaitan dengan zakat sebagai pengurang penghasilan kena pajak. Sumber data yang digunakan berupa data primer yaitu melakukan wawancara dengan pegawai dan muzaki BAZNAS Kabupaten Semarang dan data sekunder yaitu berupa dokumen BAZNAS, buku, jurnal dan artikel serta penelitian lain yang terkait dengan penelitian ini. Dalam mengumpulkan data penyusun menggunakan teknik observasi, wawancara dan dokumentasi. Sedangkan teknik mengalisis data penyusun menggunakan teknik diskriptif analisis yaitu prosedur atau cara memecahkan masalah penelitian dengan memaparkan keadaan objek yang diselidiki bagaimana adanya berdasarkan fakta yang aktual pada masa sekarang. 


\section{At-Taqaddum}

Vol. 11 No. 2 (2019) pp 142-167

DOI: http://dx.doi.org/10.21580/at.v1li2.4445

\section{Hasil dan Pembahasan}

Implementasi zakat penghasilan sebagai pengurang penghasilan kena pajak orang pribadi pada Muzaki di BAZNAS Kabupaten Semarang

Peraturan perpajakan mengenai zakat dilakukan oleh Pemerintah untuk mendorong Wajib Pajak dan Muzaki agar dapat menunaikan kedua kewajiban tersebut dengan baik. Untuk mengatasi hal tersebut pemerintah membuat peraturan yang dapat menjadi solusi antara kewajiban membayar pajak dan zakat yaitu adanya Undang-Undang Nomor 23 Tahun 2011 Pasal 22 yang berbunyi zakat yang dibayarkan oleh muzaki kepada BAZNAS dan LAZ dapat diperhitungkan sebagai pengurang Penghasilan Kena Pajak pada Pajak Penghasilan ${ }^{32}$, kemudian UndangUndang Nomor 36 Tahun 2008 tentang Pajak Penghasilan yang diatur dalam Pasal 4 ayat (3) huruf a nomor 1 yang berbunyi "yang dikecualikan dari objek pajak adalah bantuan atau sumbangan, termasuk zakat yang diterima oleh Badan Amil Zakat atau Lembaga Amil Zakat yang dibentuk dan disahkan oleh Pemerintah dan yang diterima oleh penerima zakat yang berhak atau sumbangan kegamaan yang sifatnya wajib bagi pemeluk agama yang diakui di Indonesia, yang diterima oleh lembaga keagamaan yang dibentuk dan disahkan oleh pemerintah dan yang diterima oleh penerima sumbangan yang berhak, yang ketentuannya diatur berdasarkan Peraturan Pemerintah. ${ }^{33}$

Implemetasi zakat penghasilan sebagai pengurang penghasilan kena pajak pada Muzaki di BAZNAS Kabupaten Semarang yang juga merupakan Wajib Pajak Orang Pribadi, sudah ada dan mekanisme pembayaran zakat sebagai pengurang penghasilan kena pajak sudah sesuai dengan peraturan Dirjen Pajak yang berlaku. Muzaki menyertakan Bukti Setor Zakat ketika pelaporan SPT Tahunan dan mendapatkan pengurangan dari zakat yang telah dibayarkannya. Akan tetapi Muzaki

\footnotetext{
32Undang-Undang Republik Indonesia Nomor 23 Tahun 2011 Pasal 22 Tentang Pengelolaan Zakat

${ }^{33}$ Undang-Undang Republik Indonesia Nomor 36 Tahun 2008 Pasal 4 ayat (3) huruf a nomor 1 Tentang Pajak Penghasilan
} 
yang melakukan dan menerapkan kebijakan tersebut masih relatif rendah karena hanya sedikit yang tahu akan kebijakan perlakuan zakat penghasilan sebagai pengurang penghasilan kena pajak.

Hal ini terjadi karena kurangnya sosialisasi khusus mengenai perlakuan zakat sebagai pengurang penghasilan kena pajak kepada masyarakat terutama pada Wajib Pajak Orang Pribadi baik dari pihak KPP Pratama dan BAZNAS Kabupaten Semarang. Selain itu, hal lain juga yang menjadi kendala selain kurangnya sosialisasi yaitu kurang percayanya masyarakat terhadap lembaga pengelola zakat yang menyebabkan dari masyarakat lebih memilih menyalurkan sendiri zakatnya kepada orang yang menurut mereka berhak menerima yang biasanya lebih mengutamakan tetangga atau saudara terdekat mereka. ${ }^{34}$

\section{Contoh perhitungan zakat dan pajak}

Ketentuan dan perhitungan zakat sebagai pengurang penghasilan kena pajak sudah diatur dalam undang - undang perpajakan. Untuk menghitung PKP bagi wajib pajak orang pribadi yaitu dengan cara penghasilan netto dikurangi dengan penghasilan tidak kena pajak (PTKP). Besarnya PTKP ditentukan berdasarkan status wajib pajak yang bersangkutan.

\section{Studi Kasus I}

Ibu A adalah seorang muslim dan bekerja sebagai pegawai, dengan status sudah menikah dan mempunyai dua anak $(\mathrm{K} / 02)$ serta mempunyai NPWP dengan gaji sebesar Rp 66.000.000,- setahun. Selanjutnya Ibu A membayarkan zakat profesinya di BAZNAS Kabupaten Semarang sesuai dengan Peraturan Direktur Jenderal Pajak Nomor PER-15/PJ/2012.

Ilustrasi perhitungan dari pajak penghasilan terutang adalah sebagai berikut:

\footnotetext{
${ }^{34}$ Wawancara dengan Bapak Abdul Kholiq, Staff Pengumpulan BAZNAS Kabupaten Semarang.
} 


\section{At-Taqaddum}

Vol. 11 No. 2 (2019) pp 142-167

DOI: http://dx.doi.org/10.21580/at.v1li2.4445

Tabel 2. Perhitungan pajak penghasilan

\begin{tabular}{|l|l|}
\hline Penghasilan Neto & Rp. 66.000 .000 \\
\hline (-) PTKP $(\mathrm{K} / 2)$ & $\underline{\text { Rp. } 63.000 .000}-$ \\
\hline PKP & Rp. 3.000 .000 \\
\hline PPh 21 terutang $(5 \% \times$ PKP) & Rp. 150.000 \\
\hline
\end{tabular}

Dari perhitungan diatas, besarnya pajak terutang adalah sebesar Rp 150.000,- dalam setahun. Karena Ibu A membayarkan zakatnya di BAZNAS kabupaten Semarang yang merupakan Badan Amil Zakat yang dibentuk atau disahkan oleh Pemerintah, maka Ibu A mendapatkan Bukti Setor Zakat (BZS). Bukti inilah yang bisa digunakan untuk melakukan pengurangan pada saat melakukan pembayaran pajak.

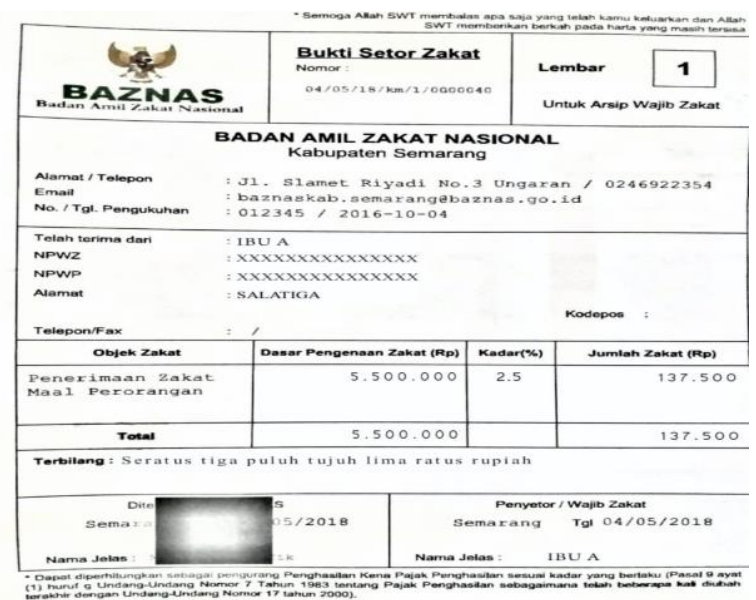

Gambar 1. Bukti Setor Zakat Ibu A

Sumber: Dokumen BAZNAS Kabupaten Semarang,

Selanjutnya Ibu A membawa Bukti Setor Zakat (BSZ) ketika melakukan pembayaran Pajak di Kantor Pajak. Maka Ilustrasi perhitungan zakat sebagai pengurang pajak adalah sebagai berikut: 
Tabel 3. Perhitungan zakat sebagai pengurang pajak

\begin{tabular}{|l|c|}
\hline Penghasilan Neto & Rp. 66.000.000 \\
\hline (-) Zakat & Rp. 1.650 .000 \\
\hline Penghasilan Neto setelah zakat & Rp. 64.350 .000 \\
\hline$(-)$ PTKP $(K / 2)$ & $\underline{\text { Rp. } 63.000 .000}$ \\
\hline PKP & Rp. 1.350 .000 \\
\hline PPh 21 terutang (5\% x PKP) & Rp. 67.500 \\
\hline
\end{tabular}

Dari perhitungan PPh $21 \mathrm{Ibu}$ A besarnya pajak terutang setelah dikurangi dengan zakat adalah sebesar Rp 67.500.

Dari kedua perhitungan diatas, dapat diketahui setelah Ibu A menjadikan zakat sebagai pengurang penghasilan kena pajak dari wajib pajak, maka PPh terutang 21 yang dibayarkan Bu A dapat berkurang sebesar Rp 82.500,-.

\section{Studi kasus 2}

Bapak B adalah seorang pekerja wiraswasta yang beragama Islam dan merupakan Wajib Pajak yang sudah menikah dan mempunyai dua orang anak (T/2) serta mempunyai NPWP. Berpenghasilan sebesar Rp 102.000.000,-/setahun. Selanjutnya Bapak B membayarkan zakat profesinya di BAZNAS Kabupaten Semarang sesuai dengan peraturan Direktur Jenderal Pajak Nomor PER-15/PJ/2012.

Berikut ilustrasi perhitungan dari pajak penghasilan Bapak B:

Tabel 4. Perhitungan pajak penghasilan

\begin{tabular}{|l|l|}
\hline Penghasilan Bruto & Rp. 102.000 .000 \\
\hline Pengeluaran & Rp. $24.000 .000-$ \\
\hline Penghasilan Neto setahun & Rp. 78.000 .000 \\
\hline (-) PTKP $(\mathrm{K} / 2)$ & $\underline{\text { Rp. } 63.000 .000}$ - \\
\hline
\end{tabular}




\section{At-Taqaddum}

Vol. 11 No. 2 (2019) pp 142-167

DOI: http://dx.doi.org/10.21580/at.v11i2.4445

\begin{tabular}{|l|rr|}
\hline PKP & Rp & 15.000 .000 \\
\hline PPh 21 terutang $(5 \%$ x PKP $)$ & Rp. & 750.000 \\
\hline
\end{tabular}

Dari perhitungan diatas, besarnya pajak terutang adalah sebesar $\mathrm{Rp}$ 750.000,- dalam setahun.

Karena Bapak B membayarkan zakatnya di BAZNAS Kabupaten Semarang yang merupakan lembaga yang dibentuk dan disahkan oleh Pemerintah, maka Bapak B mendapatkan Bukti Setor Zakat yang selanjutnya digunakan sebagai pengurang penghasilan kena pajak ketika melakukan pembayaran pajak di Kantor Pajak.

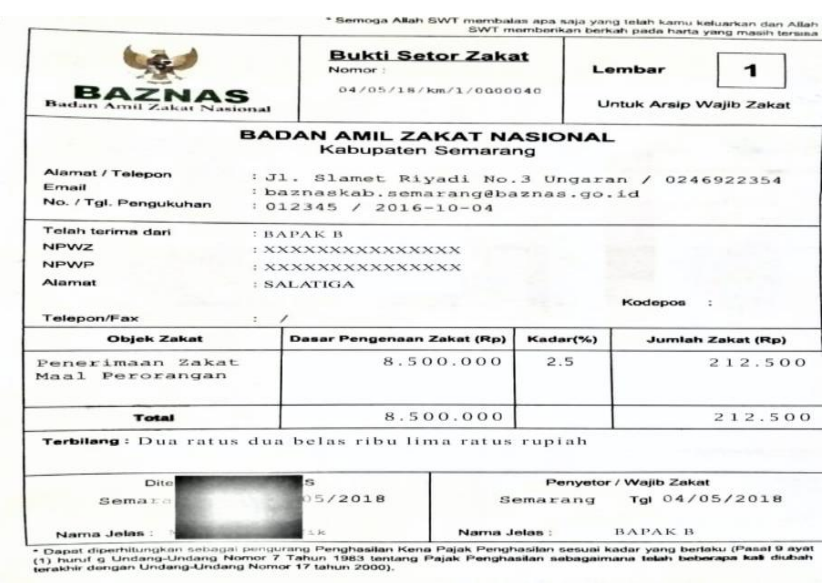

Gambar 2. Bukti Setor Zakat Bapak B

Sumber: Dokumen BAZNAS Kabupaten Semarang, data diolah sendiri.

Adapun ilustrasi perhitungan zakat sebagai pengurang pajak sebagai berikut:

Tabel 5. Perhitungan zakat sebagai pengurang pajak

\begin{tabular}{|l|c|}
\hline Penghasilan Bruto & Rp. 102.000 .000 \\
\hline Pengeluaran & Rp. $\underline{24.000 .000-}$ \\
\hline Pengahsilan Neto setahun & Rp. 78.000 .000 \\
\hline (-) Zakat & $\underline{\text { Rp. } 2.550 .000}-$ \\
\hline
\end{tabular}




\begin{tabular}{|l|lc|}
\hline Penghasilan Neto setelah zakat & Rp. & 74.450 .000 \\
\hline$(-)$ PTKP $(\mathrm{K} / 2)$ & $\underline{\text { Rp. }} \quad 63.000 .000-$ \\
\hline PKP & Rp. & 12.450 .000 \\
\hline PPh 21 terutang $(5 \% \times$ PKP) & Rp. & 622.500 \\
\hline
\end{tabular}

Dari perhitungan $\mathrm{PPh} 21 \mathrm{Ibu} A$ besarnya pajak terutang setelah dikurangi dengan zakat adalah sebesar Rp 622.500

\section{Dampak dari Implementasi Zakat Penghasilan Sebagai Pengurang Penghasilan Kena Pajak Orang Pribadi Bagi Pendapatan Negara dan Kesejahteraan Masyarakat.}

Menurut Ilfi (2008) dalam peradaban Islam dikenal dua lembaga yang menjadi pilar kesejahteraan masyarakat dan kemakmuran negara yaitu lembaga zakat dan lembaga pajak karena sifatnya adalah wajib. Pada prinsipnya zakat dan pajak adalah dua kewajiban yang mempunyai dasar berpijak berlainan. Zakat merupakan kewajiban bagi umat Islam yang mengacu pada ketentuan syariat dan hukum Allah SWT baik dalam proses pemungutannya dan penggunaannya, sedangkan pajak berpijak pada peraturan perundang-undangan yang ditentukan oleh Ulil Amri/ pemerintah menyangkut pemungutan maupun penggunaanya. ${ }^{35}$

Pajak mempunyai peranan penting dalam suatu negara karena pajak merupakan sumber utama penerimaan negara yang digunakan untuk membiayai pengeluaran negara. Selain pajak, zakat juga mempunyai peranan penting dalam distribusi pendapatan dan kekayaan. Karena didalam zakat terdapat ketentuan bahwa ia bersifat tetap dan terusmenerus, ia tetap ada selama agama Islam dan umatnya juga ada, tidak ada seseorang atau penguasa dapat menghapus zakat sebab zakat memiliki posisi seperti sholat yang bersifat abadi hingga akhir zaman. Perlakuan zakat sebagai pengurang penghasilan kena pajak sendiri jelas akan sangat berpengaruh terhadap penerimaan pajak yang menjadi kecil, semakin

35Thamrin Logawali, Peranan Zakat Sebagai Pengurang Penghasilan Kena Pajak di Kantor Kementerian Agama Kabupaten Gowa, LAA MAYSIR, Vil. 5 No. 1, Juni 2018, h. 156 


\section{At-Taqaddum}

Vol. 11 No. 2 (2019) pp 142-167

DOI: http://dx.doi.org/10.21580/at.v11i2.4445

banyak umat Islam yang membayarkan zakatnya di Badan Amil Zakat atau Lembaga Amil Zakat yang dibentuk dan disahkan oleh Pemerintah maka akan mengakibatkan semakin banyaknya pengurang penghasilan kena pajak.

Akan tetapi jika dikaji secara lebih lanjut, efek zakat sebagai pengurang penghasilan kena pajak berpengaruh terhadap pendapatan nasional, sekalipun hal itu dapat mengurangi pendapatan negara disektor pajak, tetapi kondisi perekonomian secara makro tetap membaik. Bila zakat dapat dijadikan sebagi pengurang penghasilan kena pajak, maka zakat dapat menjadi instrumen pendukung dari program-program pemerintah. Jadi, jika zakat dapat dikelola dengan baik oleh pemerintah untuk kepentingan sosial, maka permasalahan kemiskinan yang ada di Indonesia dapat diatasi. Selain itu apabila zakat yang terkumpul semakin besar hal tersebut menguntungkan masyarakat, karena Badan Amil Zakat atau Lembaga Amil Zakat tersebut menyalurkan zakat yang telah terkumpul kepada yang berhak menerimanya sesuai dengan ketentuan hukum Islam. Penyaluran kepada mustahik harus bersifat hibah (bantuan) dan harus diperhatikan skala prioritas kebutuhan mustahik diwilayah masing-masing tersebut untuk kepentingan masyarakat.

Setidaknya ada beberapa dampak positif dari adanya perlakuan tersebut, diantaranya:

1. Dengan adanya pelakuan zakat sebagai pengurang pajak, maka akan semakin banyak umat islam yang membayarkan zakat dan juga pajaknya. Hal ini disebabkan karena tidak terjadi lagi beban ganda yang harus ditanggung.

2. Dengan semakin banyaknya masyarakat yang membayarkan zakatnya di lembaga yang sudah dibentuk atau disahkan pemerintah tersebut bisa menjadi alternatife sumber penerimaan negara yang potensinya lumayan besar. Bagi wajib pajak, semakin besar zakat yang dibayarkan maka akan semakin memperingan jumlah pajak yang harus dibayarkan. Sementara bagi masyarakat yang belum memiliki kewajiban pajak justru bisa dijaring untuk menambah pemasukan negara dari kesadarannya dalam membayarkan zakat, karena bisa jadi 
ada wajib zakat yang juga wajib pajak dan ada pula yang wajib zakat yang belum menjadi wajib pajak. Dengan demikian potensi penerimaan negara bisa dioptimalkan.

3. Data-data perhitungan dan pembayaran zakat yang dilakukan oleh wajib pajak maupun non wajib pajak sesungguhnya bisa menjadi informasi penting dalam pengawasan berkaitan dengan kepatuhan dalam membayarkan pajak.

4. Dapat mengentaskan kemiskinan, menciptakan lapangan kerja dan memperkuat kekeluargaan dengan tidak ada ketimpangan antara si kaya dan si miskin yang dapat meminimalisir kecemburuan sosial.

Ketika kebijakan tersebut diterapkan oleh seluruh masyarakat muslim yang ada di Kabupaten Semarang, dimana masyarakat membayarkan zakatnya di Badan atau Lembaga yang disahkan oleh Pemerintah maka jumlah pendapatan negara dari pembayaran zakat akan meningkat sekalipun dari penerimaan pajak berkurang. Maka peran zakat dalam membangun ekonomi bangsa yaitu dalam hal mengurangi kemiskinan dan mensejahterakan masyarakat dapat dilihat dan dirasakan oleh masyarakat. Peran dari Badan atau Lembaga pengelola zakat juga tidak dapat dilepaskan dari hal ini karena mereka telah berhasil mengelola zakat yang terkumpul untuk disalurkan kepada golongan yang berhak. Dana tersebut akan disalurkan secara merata kepada seluruh lapisan masyarakat yang berhak menerimanya, selain itu dana tersebut juga bisa digunakan oleh Badan atau Lembaga Amil Zakat untuk mendirikan fasilitas kesehatan dan pendidikan untuk masyarakat yang ada disekitar yang tidak mampu.

Kenyataannya dilingkup Kabupaten Semarang penerapan zakat penghasilan sebagai pengurang penghasilan kena pajak masih minim dilaksanakan dan diterapkan karena Wajib Pajak Orang Pribadi yang tahu dan menerapkan perlakuan tersebut masih rendah sehingga belum begitu terlihat pengaruhnya terhadap penerimaan negara dari sektor pajak, selain itu juga dari pihak KPP belum melakukan pengawasan tentang zakat atas penghasilan yang dilakukan oleh wajib pajak. Hal tersebut juga disampaikan oleh Pihak KPP Pratama. 


\section{At-Taqaddum}

Vol. 11 No. 2 (2019) pp 142-167

DOI: http://dx.doi.org/10.21580/at.v11i2.4445

Sedangkan dari pihak BAZNAS sendiri dengan adanya perlakuan tersebut meningkatkan jumlah zakat yang dibayarkan oleh muzaki yang benar-benar bisa membantu pemerintah dalam mengentaskan kemiskinan. Selain disalurkan kepada masyarakat yang berhak menerima dilingkup Kabupaten Semarang, dana tersebut juga digunakan untuk program pemberdayaan yang meliputi Semarang Taqwa, Semarang Peduli; bedah rumah, tanggap peduli bencana, Semarang Sehat; layanan ambulan gratis bagi dhuafa, khitanan anak sholeh, Semarang Cerdas; beasiswa pendidikan, Semarang Makmur; mitra usaha mandiri dan bina wirausaha.

\section{Kesimpulan}

Berdasarkan pembahasan yang telah penulis lakukan diatas terkait Implementasi Zakat Penghasilan Sebagai Pengurang Penghasilan Kena Pajak Orang Pribadi Pada Muzaki di BAZNAS Kabupaten Semarang, maka dapat diambil kesimpulan bahwa Implemetasi zakat penghasilan sebagai pengurang penghasilan kena pajak pada Muzaki di BAZNAS Kabupaten Semarang sudah ada dan mekanisme pembayaran zakat sebagai pengurang penghasilan kena pajak sudah sesuai dengan Peraturan Dirjen Pajak yang berlaku. Akan tetapi muzaki yang melakukan dan menerapkan kebijakan tersebut masih relatif rendah. Hal ini terjadi karena kurangnya sosialisasi secara khusus mengenai perlakuan zakat sebagai pengurang penghasilan kena pajak kepada masyarakat terutama Wajib Pajak Orang Pribadi baik dari pihak KPP Pratama dan BAZNAS Kabupaten Semarang, selain itu juga dikarenakan kurang percayanya masyarakat terhadap lembaga pengelola zakat. Sedangkan dampak dari Implementasi Zakat Penghasilan Sebagai Pengurang Penghasilan Kena Pajak Orang Pribadi adalah meningkatkan jumlah zakat yang dibayarkan oleh muzaki yang benar-benar bisa membantu pemerintah dalam mengentaskan kemiskinan. Selain disalurkan kepada masyarakat yang berhak menerima dilingkup Kabupaten Semarang, dana tersebut juga 
digunakan untuk program pemberdayaan yang meliputi Semarang Taqwa, Semarang Peduli, Semarang Sehat, Semarang Cerdas, Semarang Makmur.

\section{Saran}

Berdasarkan hasil penelitian yang dilakukan, setelah melihat kondisi lapangan, maka ada beberapa saran dari penyusun, antara lain:

1. Perlu adanya sosialisasi khusus kepada masyarakat terkait kebijakan zakat penghasilan sebagai pengurang penghasilan kena pajak baik dari pihak BAZNAS/LAZ dan juga pihak KPP Pratama.

2. Pemerintah diharapkan dapat membuat sanksi yang tegas terkait dengan kewajiban membayar pajak.

3. Bagi wajib pajak diharapkan dapat membayarkan zakat melalui Badan Amil Zakat atau Lembaga Amil Zakat yang sudah disahkan Pemerintah yang dapat meringankan para Wajib Pajak dalam membayarkan Pajaknya.

\section{Referensi}

Abdurrahman al - Jaziri, al-Fiqh 'ala al-madzabib al-Arba'ah, Cairo: Mathaba'ah al-Istiqamah, cet-3, jilid IV, h. 95.

Afendi, A. (2018). Pengaruh Variabel Makroekonomi Terhadap Jumlah Penerimaan Zakat di Badan Amil Zakat Nasional (Baznas) Pusat Tahun 2012 - 2016. Muqtasid: Jurnal Ekonomi Dan Perbankan Syariah, 9(1), 54. https://doi.org/10.18326/muqtasid.v9i1.54-69

Amiruddin Inoed (ed), Anatomi Fiqih Zakat Potret \& Pemahaman Badan Amil Zakat Sumatera Selatan, Yogyakarta: Pustaka Pelajar,2005, h. 8.

Apriliana, Analisis Komparatif Antara Perlakuan Zakat Sebagai Pengurang Penghasilan Kena Pajak Dengan Perlakuan Zakat Sebagai Pengurang Langsung Pajak Penghasilan, Skripsi, Jakarta: UIN Syarif Hidayatullah, 2010, h. 31. 


\section{At-Taqaddum}

Vol. 11 No. 2 (2019) pp 142-167

DOI: http://dx.doi.org/10.21580/at.v1li2.4445

Fitha Fathya, Perlakuan Zakat Sebagai Pengurang Pajak Penghasilan Pada Badan Amil Zakat (BAZ) Provinsi Jawa Timur, Malang: UIN Maulana Malik Ibrahim, 2014.

Herry Purwanto, Dasar-dasar Perpajakan \& Akuntansi Pajak, Jakarta: Erlangga, 2010, h. 7.

Intan Oktavia Angga Mawarni, Zakat Sebagai Pengurang Penghasilan Kena Pajak Studi Penerapan Atas Pasal 22 dan 23 Tentang Zakat Sebagai Pengurang Pajak UU No. 23 Tahun 2011 Di Dompet Dhuafa Yogyakarta, Yogyakarta: UIN Sunan Kalijaga, 2016.

Kementerian Agama RI, Ummul Mukminin Al-Qur'an dan Terjemaban untuk Wanita, Jakarta: wali oasis terrace recident, 2016, h. 4

Keputusan Direktur Jenderal Pajak Nomor KEP-163/PJ/2003 tentang perlakuan zakat atas penghasilan dalam perhitungan penghasilan kena pajak pajak penghasilan.

Mariah, Zakat Sebagai Pengurang Penghasilan Kena Pajak Studi Kasus Terbadap Pelaksanaan Undang-Undang Zakat di Kabupaten Bekasi, Jakarta: UIN Syarif Hidayatulloh, 2011.

Peraturan Direktur Jenderal Pajak Nomor PER-6/PJ/2011 Pasal 1 huruf a tentang Pelaksanaan Pembayaran dan Pembuatan Bukti Pembayaran atas Zakat atau Sumbangan Keagamaan yang sifatnya wajib yang dapat dikurangkan dari penghasilan bruto.

Peraturan Direktur Jenderal Pajak Nomor PER-11/PJ/2017 tentang badan/lembaga yang dibentuk atau disahkan oleh Pemerintah yan ditetapkan sebagai penerima zakat atau sumbagan keagamaan yang sifatnya wajib yang dapat dikurangkan dari penghasilan bruto.

Peraturan Menteri Keuangan Nomor 254/PMK.03/2010 tentang tata cara pembebanan zakat atau sumbangan keagamaan yang sifatnya wajib yang dapat dikurangkan dari penghasilan bruto.

Peraturan Direktur Jenderal Pajak Nomor PER-6/PJ/2011 tentang pelaksanaan pembayaran dan pembuatan bukti pembayaran atas zakat atau sumbangan keagamaan yang sifatnya wajib yang dapat dikurangkan dari penghasilan bruto 
Selfiana Ferida Lubis, Analisis Yuridis Terhadap Pembayaran Zakat Dalam Pengadaan Pajak Penghasilan, Jurnal, Medan: Universitas Sumatera Utara, 2014.

Sri Andriani, Zakat Sebagai Pengurang Pajak Penghasilan Pada Badan Amil Zakat, JRAK Vol. 4 No. 1, Februari 2013, h. 15.

Saifudin Zuhri, Zakat di Era Reformasi (Tata kelola Baru) Undang- Undang Pengelolaan Zakat No. 23 Tahun 2011, Semarang: Fakultas Tarbiyah IAIN Walisongo Semarang, 2012, h. 1.

Undang-Undang Nomor 23 Tahun 2011 Pasal 22 Tentang Pengelolaan Zakat.

Undang-Undang Nomor 23 Tahun 2011 Pasal 4 ayat 1 Tentang Pengelolaan Zakat.

Undang-Undang Nomor 36 Pasal 4 ayat (1) Tahun 2008 Tentang Pajak Penghasilan.

Undang-Undang Republik Indonesia Nomor 23 Tahun 2011 Pasal 22 Tentang Pengelolaan Zakat

Undang-Undang Republik Indonesia Nomor 36 Tahun 2008 Pasal 4 ayat (3) huruf a nomor 1 Tentang Pajak Penghasilan

Thamrin Logawali, Peranan Zakat Sebagai Pengurang Penghasilan Kena Pajak di Kantor Kementerian Agama Kabupaten Gowa, LAA MAYSIR, Vil. 5 No. 1, Juni 2018, h. 156

Wahbah az-Zuhaili, Fiqih Zakat Dalam Dunia Modern, Surabaya: Bintang, 2001, h. 01.

Wawancara dengan Bapak Abdul Kholiq, Staff Pengumpulan BAZNAS Kabupaten Semarang.

Dokumen BAZNAS Kabupaten Semarang

www.kemenkeu.go.id/apbn2018

www.online-pajak.com

www.bps.go.id (Badan Pusat Statistik, Population Census 2010) 